\title{
A Study of the Abnormal Lipoproteins in Abetalipoproteinemia
}

\author{
Angelo M. Scanu, Lawrence P. Aggerbeck, Arthur W. Kruski, \\ Chang T. Lim, and Herbert J. Kayden \\ From the Departments of Medicine and Biochemistry of the Pritzker School \\ of Medicine of the University of Chicago and the Franklin McLean Memorial \\ Research Institute, Chicago, Illinois 60637
}

A B S TRACT The serum lipoproteins of five patients with abetalipoproteinemia (ABL) were separated by ultracentrifugation and then analyzed either intact or after delipidation. In accord with previous findings, all of the patients lacked serum particles with the characteristics of normal low-density lipoproteins (LDL) and of the LDL apoprotein as assessed by immunochemical methods. Each patient exhibited on every examination an abnormal particle, "LDL", which had the flotational properties of LDL, the polypeptide makeup of highdensity lipoproteins HDL, the spectral and morphological characteristics of neither LDL nor HDL, and a relatively low content of cholesteryl esters. The HDL were abnormal in having a marked decrease in their total plasma content, an altered proportion of the subclasses $\mathrm{HDL}_{2}$ and $\mathrm{HDL}_{\mathbf{3}}$, and a peculiar polypeptide distribution, comprising both normal and additional components, usually not seen in normal controls. The patients also exhibited a decrease of plasma lecithin-cholesterol acyl transferase (LCAT) activity which probably accounted for the low content of cholesteryl esters in both "LDL" and HDL, and in turn for the unusual appearance of "LDL" on electron microscopy.

This work was presented in part at the Annual Meeting of the American Heart Association, Dallas, Texas, November 16, 1972, and published in abstract form in Circulation, 46 (Supplement II) : 18 (1972).

Dr. Scanu is the recipient of U. S. Public Health Service Career Development Award HL 24867.

Dr. Kruski is the recipient of U. S. P. H. S. Post-Doctoral Fellowship HL 52970.

Dr. Aggerbeck is the recipient of U. S. P. H. S. Grant HD 00001 from the National Institute of Child Health and Human Development.

Dr. Kayden's address is: Department of Medicine, New York University School of Medicine, New York.

Received for publication 8 May 1973 and in revised form 13 August 1973.
It is concluded that $\mathrm{ABL}$ is a disorder affecting all serum lipoprotein classes. Whether the abetalipoproteinemia previously described and noted in the current studies is related to or independent of the abnormalities observed in the other lipoproteins was not established. How the deficiency of LCAT activity, observed in all patients studied, contributed to some of the observed structural lipoprotein abnormalities also remained undetermined.

\section{INTRODUCTION}

It now appears to be accepted, primarily on the basis of immunological data, that the protein normally found in low-density lipoproteins (LDL), ${ }^{1}$ is absent from the plasma of patients with abetalipoproteinemia (ABL) (1-3). This defect is a key feature of ABL. Physical and chemical abnormalities in circulating high-density lipoproteins (HDL) have previously been reported but have not been completely defined (1-3). Moreover, small quantities of lipoproteins floating in the density range of LDL have been recognized in patients with $A B L$ and, from chemical and immunological data, considered fatrich but otherwise normal HDL (4). Since this 3-yrstudy was undertaken, Gotto, Levy, John, and Fredrickson (5) have studied the lipoprotein apoproteins of

${ }^{1}$ Abbreviations used in this paper: ABL, abetalipoproteinemia, ACD, acid citrate dextrose; apo VLDL, apo LDL, apo $\mathrm{HDL}_{2}$, apo $\mathrm{HDL}_{3}$, and apo $\mathrm{VHDL}_{1}$ refer to the delipidated apoproteins of VLDL, $\mathrm{LDL}_{2}, \mathrm{HDL}_{2}, \mathrm{HDL}_{3}$, and VHDL $_{1}$, respectively; DTT, dithiothreotal ; HDL, highdensity lipoprotein; HDL, HDL of $d 1.063-1.125 \mathrm{~g} / \mathrm{ml}$; $\mathrm{HDL}_{3}$, HDL of $d 1.125-1.21 \mathrm{~g} / \mathrm{ml}$; LCAT, lecithin: cholesterol acyl transferase; LDL, low-density lipoproteins; $\mathrm{LDL}_{1}$, LDL of $d 1.006-1.019 \mathrm{~g} / \mathrm{ml}$; LDL, LDL of $d$ $1.019-1.063 \mathrm{~g} / \mathrm{ml}$; SDS, sodium dodecylsulphate; VHDL 1 , HDL of $d 1.21-1.25 \mathrm{~g} / \mathrm{ml}$; VIDL, very low-density lipoproteins of $d 1.006 \mathrm{~g} / \mathrm{ml}$. 
abetalipoproteinemic plasma and recognized the absence of one of the $\mathrm{C}$ peptides. Moreover, Forte and Nichols (6) reported electron microscopic studies indicating that in $\mathrm{ABL}$ the lipoproteins floating as LDL have an abnormal morphology.

This work is a systematic analysis carried out on the major lipoprotein classes isolated from the plasma of five patients with ABL. The results obtained, besides corroborating reported findings, also provide a firm documentation for previously unrecognized biochemical abnormalities in this disease.

\section{METHODS}

Paticnts studied. A total of five patients with ABL, who have been described previously, were studied: D. P., a 10yr-old boy (7) ; A. M. V., a 15-yr-old girl (8); M. S., an 18-yr-old male (9); R. I., a 19-yr-old male (10); and G. F., also a 19-yr-old male (11). The plasma of each patient was studied on several occasions within a 3-yr period.

Conditions of blood collection. Plasma from fasting subjects was obtained by plasmaphoresis with a final acid citrate dextrose (ACD) or sodium citrate solution to plasma ratio of $1: 10$. No differences were noted in analytical results between samples collected in ACD or in $\mathrm{Na}$ citrate. After removal of remaining red cells by centrifuga- tion in a Sorvall RC-2 Superspeed refrigerated centrifuge (Ivan Sorvall, Inc., Newtown, Conn.) with a Sorvall GSA rotor at $4,080 \mathrm{~g}$ for $30 \mathrm{~min}$ at $4^{\circ} \mathrm{C}$, the plasma was made $0.001 \mathrm{M}$ in EDTA, $\mathrm{pH} 7$. Control specimens from healthy, normal subjects underwent the same fractionation procedures as the $\mathrm{ABL}$ sera. In both cases, plasma was initially centrifuged (Sorvall $\mathrm{RC}-2$ centrifuge SS-34 rotor, $12,000 g$, $15 \mathrm{~min}, 4^{\circ} \mathrm{C}$ ) to remove chylomicrons present in normal samples.

Separation of lipoproteins. Scheme 1: Under the experimental conditions used, "very low-density lipoproteins" ("VLDL"), "LDL", $\mathrm{HDL}_{2}$ and $\mathrm{HDL}_{3}$ were sequentially floated at the top of the centrifuge tubes, with the use of a Beckman L2 65-B ultracentrifuge (Beckman Instruments, Inc., Spinco Div., Palo Alto, Calif.) and Spinco 30.2 and 40.3 rotors as indicated in Table I. Scheme 2: A first-step centrifugation was carried out to float all lipoproteins of $d$ $<1.21 \mathrm{~g} / \mathrm{ml}$. The density of the medium was then progressively diluted to obtain a "VLDL + LDL" fraction as well as $\mathrm{HDL}_{2}$ and $\mathrm{HDL}_{3}$ or whole $\mathrm{HDL}$.

When either scheme was followed, the top 1-ml fractions within each lipoprotein class were pooled. VLDL or LDL were subjected to two washings (30.2 rotor; $79,488 g, 24 \mathrm{~h}$, $16^{\circ} \mathrm{C}$ ), and $\mathrm{HDL}_{2}$ or $\mathrm{HDL}_{3}$ to three washings (40.3 rotor; $114,480 \mathrm{~g}, 24 \mathrm{~h}, 16^{\circ} \mathrm{C}$ ) to concentrate each lipoprotein species and further purify each fraction.

The isolation of very high-density lipoprotein (VHDL $\left._{1}\right)$ was carried out according to the scheme presented in

TABLE I

Fractionation Schemes for Serum Lipoproteins from Patients with ABL

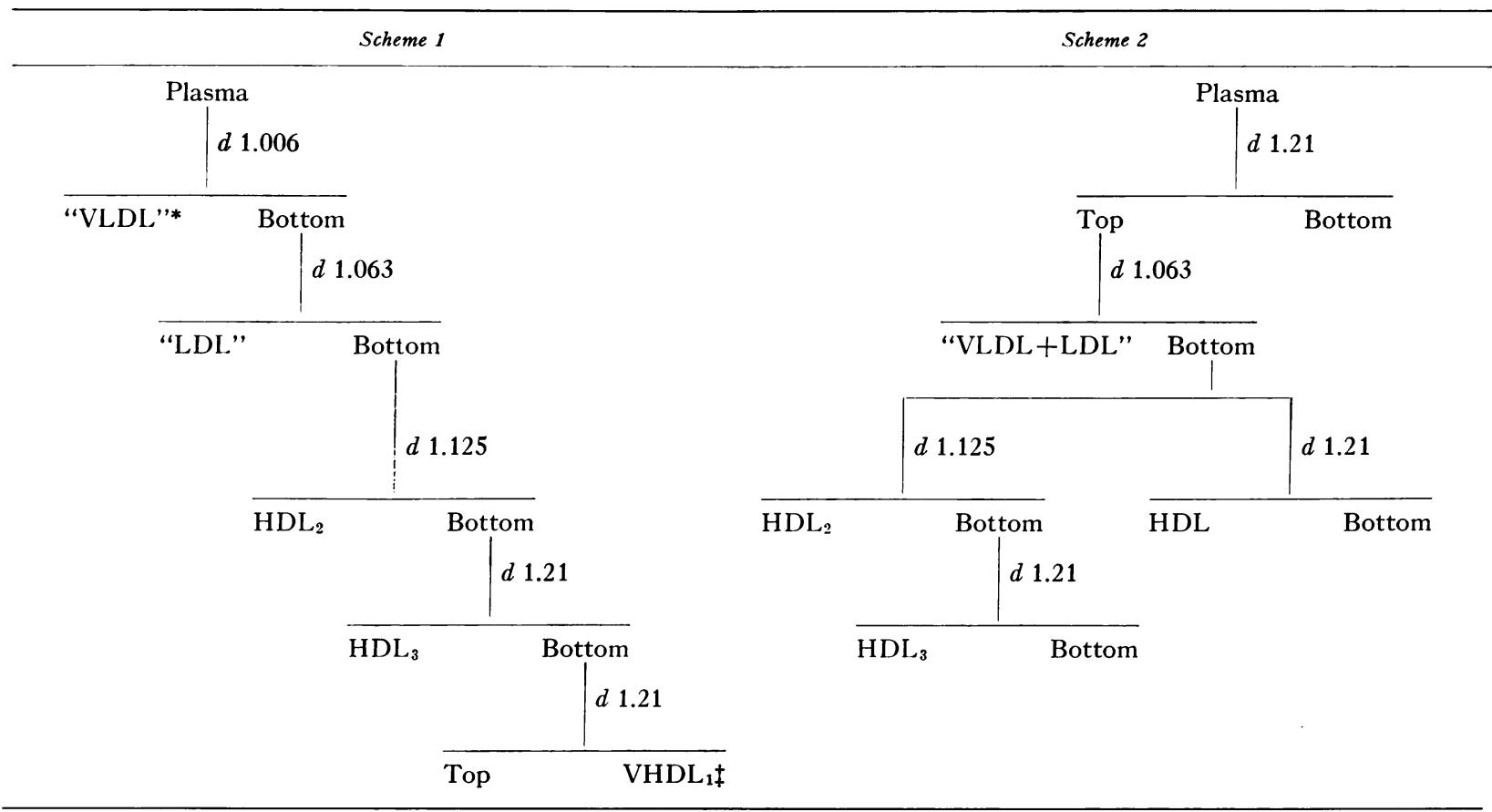

Fractionations were carried out in a Beckman Model L2-65B ultracentrifuge at $16^{\circ} \mathrm{C}$. Separations at $\left.d 1.0\right) 5$ and 1.063 were made with a Spinco 30.2 rotor $(79,488 g ; 24 \mathrm{~h})$; those at $d 1.21$ utilized Spinco 40.3 rotors $(114,480 g ; 24$ h). Densities are given in $\mathrm{g} / \mathrm{ml}$.

* Present in extremely minute amounts. Characteristics not determined.

$\ddagger$ For details on $\mathrm{VHDL}_{1}$ preparation, see Table II. 
TABLE II

Fractionation Scheme for $\operatorname{VHDL}_{1}($ d 1.21-1.25 $\mathrm{g} / \mathrm{ml})$

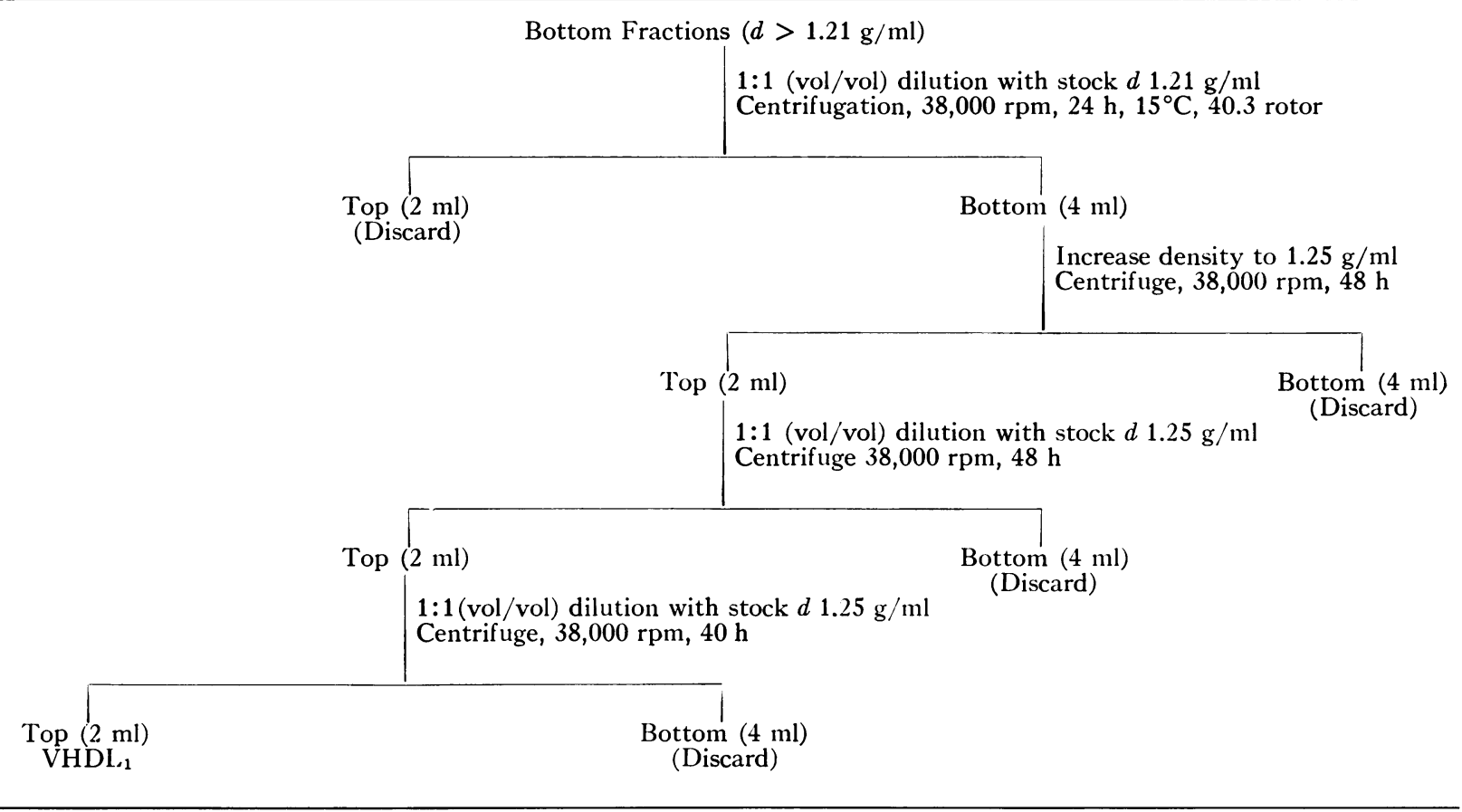

Table II. All lipoproteins were dialyzed at $4^{\circ} \mathrm{C}$ in the dark with more than five changes of dialysate against a 50 -fold volume of $0.15 \mathrm{M} \mathrm{NaCl}, 0.05 \%$ EDTA, adjusted to $\mathrm{pH}$ 7.0 with $\mathrm{NaOH}$. The fractions were stored at $4^{\circ} \mathrm{C}$, usually not longer than $48 \mathrm{~h}$.

Delipidation procedures. Delipidation procedures were conducted as outlined previously (12), with the exception that, for "VILDL" and "LDL", the technique was adapted to a "miniscale" operation, in which glass-stoppered $10-\mathrm{ml}$ centrifuge tubes were used. For HDL, the ethanol-ether procedure was applied, and for "VLDL" and "LDL" the chloroform-methanol method. The delipidated apoproteins were stored at $10^{\circ} \mathrm{C}$ until used.

Studies on the intact particles. The particles were visualized by electron microscopy with the technique of negative staining (13). Circular dichroic measurements were made as previously described (14). For immunological characterization, double immunodiffusion and immunoelectrophoretic techniques in $1 \%$ agarose were carried out with antisera prepared against normal serum HDL and LDL as well as against normal apo HDL, apo A-I, apo A-II, and apo C (14). Whole lipoproteins were also analyzed by sodium dodecyl sulfate (SDS)-polyacrylamide gel electrophoresis (15), a technique that proved capable of producing both delipidation and fractionation of the essentially lipid-free apoprotein.

Density gradient studies were carried out in a Spinco SW-40 rotor utilizing Spinco Model L2-65 B ultracentrifuges, at $38,000 \mathrm{rpm}, 20^{\circ} \mathrm{C}$, for $66 \mathrm{~h}$. A $13.2-\mathrm{ml}$ linear gradient of $\mathrm{CsCl}$ (Schwartz/Mann Div., Becton, Dickinson \& Co., Orangeburg, N. Y., optical grade) in $0.05 \mathrm{M}$ Tris $(\mathrm{HCl})$ buffer, $10^{-3} \mathrm{M}$ EDTA, $\mathrm{pH}$ 8.1, was established between the limiting densities of 1.209 and $1.076 \mathrm{~g} / \mathrm{ml}$. From 3 to $6 \mathrm{mg}$ of lipoprotein protein/tube was employed.
At the end of the run, 0.4- $\mathrm{ml}$ fractions were collected. Each was analyzed for protein content $(280 \mathrm{~nm}$ absorbancy or Lowry method) and, whenever indicated, subjected to SDS-polyacrylamide gel electrophoresis.

Sedimentation and flotation analyses of $\mathrm{HDL}_{2}$ and $\mathrm{HDL}_{3}$ were carried out at $20^{\circ} \mathrm{C}$ in a Beckman Model E Analytical Ultracentrifuge with an AN-D rotor and a double sector cell equipped with sapphire windows. Sedimentation studies were carried out at $d 1.006 \mathrm{~g} / \mathrm{ml}, 40,000 \mathrm{rpm}$ and flotation studies at $d 1.21 \mathrm{~g} / \mathrm{ml}, 42,040 \mathrm{rpm}$.

Studies on the delipidated apoproteins. Because of the small amount of material available, the analysis of "LDL" was limited to spectral, electrophoretic, and immunological studies. Polyacrylamide gel electrophoresis in $8 \mathrm{M}$ urea was performed as previously described (14).

The apo HDL polypeptides were fractionated by Sephadex G-200 column chromatography in $8 \mathrm{M}$ urea (14) and purified as described previously $(16,17)$. Apo HDL, normal or ABL, was also fractionated by DEAE column chromatography $(2.5 \times 45-\mathrm{cm}$ columns $)$ with a linear gradient of Tris $(\mathrm{HCl}), \mathrm{pH} 8.2,6 \mathrm{M}$ urea buffer, in the range of $0.03-0.07 \mathrm{M}$ concentration. The flow rate was $14-15 \mathrm{ml} / \mathrm{h}$ with an average protein load of $50 \mathrm{mg} /$ column. Absorbance at $280 \mathrm{~nm}$ was monitored continuously, and the urea was removed by dialysis. The Sephadex fraction V, which comprises the $\mathrm{C}$ apolipoproteins, was fractionated further by DEAE cellulose column chromatography with $1.6 \times 45-\mathrm{cm}$ columns and a linear gradient, 0.01-0.1 M Tris $(\mathrm{HCl}), \mathrm{pH} 8.2$, in $6 \mathrm{M}$ urea.

Either apo HDL or the apo HDL $C$ peptides, were subjected to cleavage by the enzyme neuraminidase (Calbiochem, San Diego, Calif.). Treatment with neuraminidase was carried out in $0.1 \mathrm{M}$ sodium acetate, $0.001 \mathrm{M}$ calcium chloride, $4 \mathrm{M}$ urea at $\mathrm{pH} 5.6$, for $16 \mathrm{~h}$ at $37^{\circ} \mathrm{C}$ with con- 
stant agitation. Samples incubated with neuraminidase contained $50 \mathrm{U}$ of enzyme/mg of protein. Control samples were incubated without enzyme under the same conditions. Further control samples with neither incubation nor enzyme were also examined. After incubation, samples were analyzed by polyacrylamide gel electrophoresis in $8 \mathrm{M}$ urea and by polyacrylamide gel electrophoresis in SDS, and then fractionated by DEAE ion-exchange chromatography (see Results). In all of the above experiments, the completeness of the enzymatic cleavage was checked by chemical determinations of sialic acid (14).

Amino acid analyses of hydrolyzed samples were performed as described previously (16) except for the analyses of the "intermediate" which, because of the low amounts of pure material available, were carried out in triplicate in a Durrum Model D-500 amino acid analyzer (Durrum Instrument Corp., Palo Alto, Calif.) with a single column system and sodium citrate buffers. Acidic and neutral amino acids were eluted at $53^{\circ} \mathrm{C}$, and the basic at $62^{\circ} \mathrm{C}$.

Chemical analyses. Protein content was determined in triplicate by the method of Lowry, Rosebrough, Farr, and Randall (18), with bovine serum albumin as standard. Any turbidity that occurred was removed by brief centrifugation or extraction with diethyl ether before the absorbance was read.

Total cholesterol was determined by the method of Franey and Amador (19), phospholipid by the method of Chen, Toribara, and Warner (20), with the factor of 25 used to convert inorganic phosphorous to phospholipid and triglycerides by the method of Van Handel and Zilversmit (21). Extracts of serum, prepared by the method of Folch, were separated by thin-layer chromatography in a solvent system of petroleum ether:ethyl ether:acetic acid $90: 10: 1$, and the cholesterol ester fraction was isolated and quantified by the ferric chloride method. The fatty acids contained in the cholesterol ester, triglyceride, phospholipid, or the free fatty acids were extracted from the silica gel with chloroform:methanol 2:1 and methylated with methanol in sulfuric acid (22). They were then analyzed at $185^{\circ} \mathrm{C}$ in a Hewlett-Packard Research Model 7620 gas chromatograph (Hewlett-Packard Co., Palo Alto, Calif.) on a $6-\mathrm{ft}$ coiled stainless steel column of 1 " inner diameter packed with $10 \%$ ethylene glycol succinate-methyl silicone polymer (EGSS-X) on Gas Chrom P 100/200 mesh (Applied Science Labs, Inc., State College, $\mathrm{Pa}$.) with a flame ionization detector. Peak areas for each fatty acid were determined by an electronic digital integrator (Model $3370 \mathrm{~A}$, Hewlett-Packard). In some instances, especially during analyses of "VLDL" and "LDL", the quantities of lipid were too small to permit ordinary analytical procedures. In such cases, it was necessary to measure the cholesterol content of "VLDL" as the trimethylsilyl derivative by gas-liquid chromatography on a column of $1 \%$ Hi-EFF-3BP on 100/120 Gas Chrom Q (Applied Science Labs) at a temperature of $200^{\circ} \mathrm{C}$ with coprostanol and cholestone as double internal standards.

Lecithin:cholesterol acyl transferase (LCAT) measurements. The LCAT determinations on whole plasma from three ABL patients (G. F., M. S., and A. M. V.) were carried out according to the method of Stokke and Norum (23).

\section{RESULTS}

\section{Studies on whole lipoproteins}

" $L D L "$. In all patients studied, this fraction occurred in concentrations between 1 and $2 \mathrm{mg}$ of protein $/ 100 \mathrm{ml}$. Therefore, no analytical ultracentrifugal studies were carried out.

Electron microscopic examination of this fraction by negative staining demonstrated free-standing spherical particles (inset, Fig. 1B) with mean particle diameter of $125 \pm 15 \AA$ (SD) (range 90-160 $\AA$ ). However, the majority of particles examined (Fig. 1B) exhibited an unusual packing arrangement leading to a mosaic appearance. The particle length was $102 \pm 10 \AA$ (SD) (range 85-125 $\AA$ ). A packing arrangement of this nature was not observed with normal LDL or normal HDL. The size of these particles differs significantly from normal LDL as assessed by $t$-test.

By the technique of circular dichroism (Fig. 2) the spectrum of "LDL" from each patient was clearly distinguishable from that of normal LDL or HDL: it had a minimum at $208 \mathrm{~nm}$ with a shoulder around $222 \mathrm{~nm}$ and a crossover point at $201 \mathrm{~nm}$.

Immunologically, ABL-"LDL" showed no reactivity against normal LDL antisera, but reacted readily with antisera raised against normal HDL or its protein components, apo A-I, apo A-II, and apo C (Table III), the reaction against anti-apo A-I being the most intense. In contrast, normal control LDL reacted against anti-LDL, but not against anti-apo A-I.

Lipid studies of "LDL" demonstrated a change in the free cholesterol-to-cholesterol ester ratio, normally 30 : 70 , to an average value of $41: 59$ for the five patients (Table IV). In addition, the ratio of lecithin to sphingomyelin, normally $61: 29$, was close to one in the patients studied. The analysis of the fatty acids in LDL could be carried out only in the cholesterol ester, lecithin, and sphingomyelin fractions of two patients. These measurements documented a decrease (more than 50\% normal) of the essential fatty acids: linoleic $(18: 2)$ and arachidonic $(20: 4)$. The decrease was also apparent in HDL.

$H D L$, $H D L$ s. According to recovery experiments after ultracentrifugal fractionation, both $\mathrm{HDL}_{2}$ and $\mathrm{HDL}_{3}$ were decreased from $50 \%$ to $80 \%$ of normal, depending upon the subject studied. The ratio of $\mathrm{HDL}_{2}$ : $\mathrm{HDL}_{3}$ was approximately $3: 1$ based on protein content; this is the reverse of the normal ratio. Examination by the electron microscope showed that the ABL fractions $\mathrm{HDL}_{2}, \mathrm{HDL}_{3}$, and HDL were similar to their normal counterparts in morphological appearance and mean diameter. $A B L H_{2}$ had a range of particle sizes from 70 to $150 \AA$ with an average particle size of $106 \pm 20 \AA$ (SD). The range of particle size of $A B L H_{3}$ was from 80 to $160 \AA$ with an average of $117 \pm 20 \AA$ (SD). No statistical difference in mean diameters as assessed 

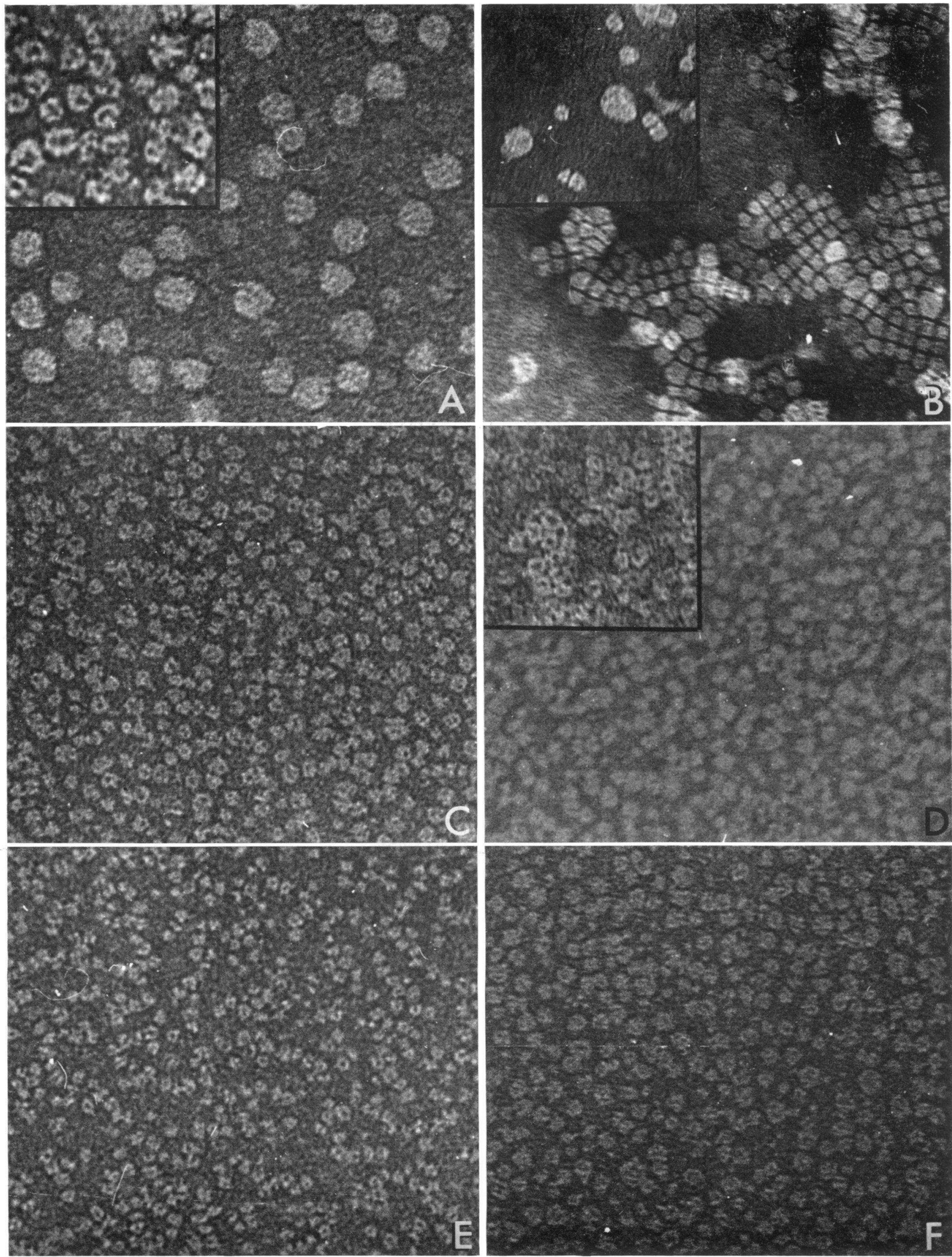

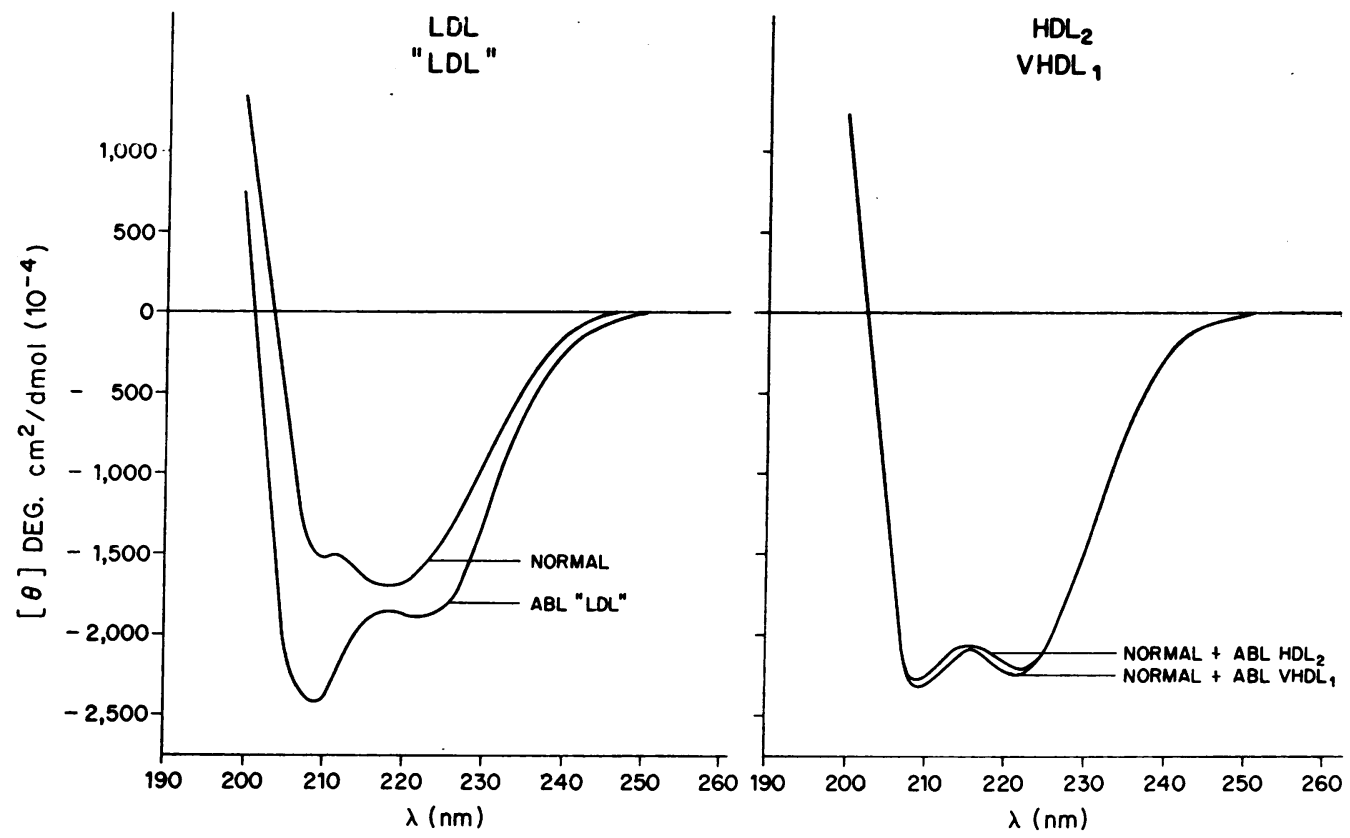

Figure 2 Circular dichroic patterns of normal LDL and "LDL" from ABL; normal HDL, and $\mathrm{ABL} \mathrm{HDL}_{2}$; normal and ABL VHDL 1 .

by the $t$-test was noted between normal and ABL HDL; or HDLs.

Flotation patterns: At a density of $1.21 \mathrm{~g} / \mathrm{ml}, \mathrm{ABL}$ $\mathrm{HDL}_{2}$ and $\mathrm{HDL}_{3}$ showed broad and asymmetric peaks with $\mathrm{F}_{20,1.21}^{\circ}$ values of $-5.3 \mathrm{~S}$ and $-2.4 \mathrm{~S}$, respectively. Sedimentation analysis of the same preparations at $d=$ $1.006 \mathrm{~g} / \mathrm{ml}$ gave sharp peaks with $\mathrm{S}^{\circ}{ }_{20,1.006}$ values of $4.55 \mathrm{~S}$ and 4.92S for HDLs and HDLs, respectively.

Circular dichroic spectra of $\mathrm{ABL} \mathrm{HDL}_{2}$ and $\mathrm{VHDL}_{1}$ were similar to their normal counterparts (Fig. 2). This was true also for HDLs (not shown in the figure). The spectra had minima at $222 \mathrm{~nm}$ and $208 \mathrm{~nm}$, with crossover at $202 \mathrm{~nm}$, as previously described for normal $\mathrm{HDL}$ and its subfractions (24).

Immunological studies (Table III) indicated that ABL $\mathrm{HDL}_{2}, \mathrm{HDL}_{3}, \mathrm{HDL}$, and VHDL 1 all reacted with antisera raised against any one of the following materials : normal apo HDL, apo A-I, apo A-II, and apo C. The results obtained were indistinguishable from those of normal controls. The ABL HDL, HDLs, HDL, and $\mathrm{VHDL}_{1}$ did not react against anti-LDL antisera.

Polyacrylamide gel electrophoretic patterns ( $0.1 \%$ $\mathrm{SDS}, 10 \%$ acrylamide) of ABL HDLs and $\mathrm{HDL}_{8}$ were significantly different from normal. The electrophoretic band pattern was indistinguishable from that obtained with delipidated apo HDL (see section on apolipoproteins), indicating that the presence of SDS in the gel caused complete or near-complete delipidation of lipoproteins. In normal controls several bands were found that had previously been identified as corresponding to Sephadex fractions I-II ${ }^{2}$, apo A-I, apo A-II, and apo C. Reduction of the disulfide bond in apo A-II with dithiothreotal (DTT) resulted in the well-known shift in its electrophoretic mobility. In all of the patients studied the apo A-I and apo A-II band pattern of ABL was the same as normal. Some distinctive features were present in the $\mathrm{ABL}$ specimens regardless of the protein load; these included: ( $a$ ) bands in the fraction I-II region ${ }^{2}$ more intensely stained than normal, one of which (indicated by arrows in Figs. 3 and 4 ) had an apparent molecular weight of about 59,000, which changed to 45,000 upon reduction; (b) the presence of two intermediate bands between apo A-I and apo A-II with apparent molecular weights of 22,000 and 20,000 , respectively, one of which was affected by reduction with either DTT or $\beta$-mercaptoethanol; and $(c)$ absence of

The terms I and II indicate the order of elution of these fractions from Sephadex columns (14). These fractions have not yet been characterized.

FIGURE 1 Electron micrographs (negative staining) of "LDL", $\mathrm{HDL}_{2}$ and $\mathrm{HDL}_{3}$ from ABL and controls. A, LDL, normal; B, "LDL", ABL; C, HDL , normal ; D, HDL2, ABL; E, $\mathrm{HDL}_{3}$, normal; F, HDL 3 , ABL. Magnification: $250,000 \times$; inset A magnification: $190,000 \times$. 
TABLE III

Summary of Immunological Results with Whole Lipoproteins of $A B L$

\begin{tabular}{lccccc}
\hline $\begin{array}{l}\text { Antigen } \backslash \text { Antibody } \\
\text { "VLDL-LDL" }\end{array}$ & $\begin{array}{c}\text { Anti- } \\
\text { LDL }\end{array}$ & $\begin{array}{c}\text { Anti } \\
\text { apo } \\
\text { HDL }\end{array}$ & $\begin{array}{c}\text { Anti } \\
\text { apo } \\
\text { A-I }\end{array}$ & $\begin{array}{c}\text { Anti } \\
\text { apo } \\
\text { A-II }\end{array}$ & $\begin{array}{c}\text { Anti } \\
\text { apo } \\
\text { C }\end{array}$ \\
\hline HDL & - & + & + & + & + \\
HDL $_{2}$ & - & + & + & + & + \\
HDL & - & + & + & + & + \\
VHDL & Bottom \\
fraction & - & + & + & + & + \\
& - & + & + & + & ND \\
\hline
\end{tabular}

ND, not determined.

one of the apo $\mathrm{C}$ bands, with a molecular weight of about 10,000 , seen in normal controls (Fig. 3).

An attempt was made to resolve the various bands with the assumption that the extra components seen in ABL HDL were members of distinct lipoprotein species. $\mathrm{ABL} \mathrm{HDL}_{2}$ or $\mathrm{HDL}_{3}$ was fractionated by density gradient ultracentrifugation and compared to controls. Normal $\mathrm{HDL}_{2}$ and $\mathrm{HDL}_{3}$ exhibited a major and a minor peak. By polyacrylamide gel electrophoresis in SDS, the major peak exhibited a band pattern similar to that of whole $\mathrm{HDL}_{2}$ or $\mathrm{HDL}_{3}$ (not shown in Fig. 5), whereas the minor peak contained essentially only apo A-I. The ABL specimens had a distinctive profile characterized by a major broad component comprising a shoulder and a peak. By polyacrylamide gel electrophoresis (see Fig. 5) both shoulder and peak contained apo A-I, apo A-II,

TABLE IV

Lipids of " $L D L "$

\begin{tabular}{cc}
\hline Patient & $\begin{array}{c}\text { Cholesterol } \\
\text { unesterified:esterified }\end{array}$ \\
\hline A. M. V. & ratio of percenlage \\
D. P. & $49: 51$ \\
M. S. & $35: 65$ \\
R. I. & $38: 62$ \\
G. F. & $49: 51$ \\
Average & $36: 64$ \\
Controls* & $41: 59$ \\
Lecithin:sphingomyelin $\ddagger$ & $30: 70$ \\
R. I. & $46: 39$ \\
A. M. V. & $39: 45$ \\
Controls & $61: 29$ \\
\hline
\end{tabular}

* Control values were obtained from normal male subjects 20-30 yrs of age with no evidence of lipid disorders.

¥ The remaining $15 \%$ of phospholipid distribution in the two patients was not significantly different from the normal controls.

Scanu, Aggerbeck, Kruski, Lim, and Kayden

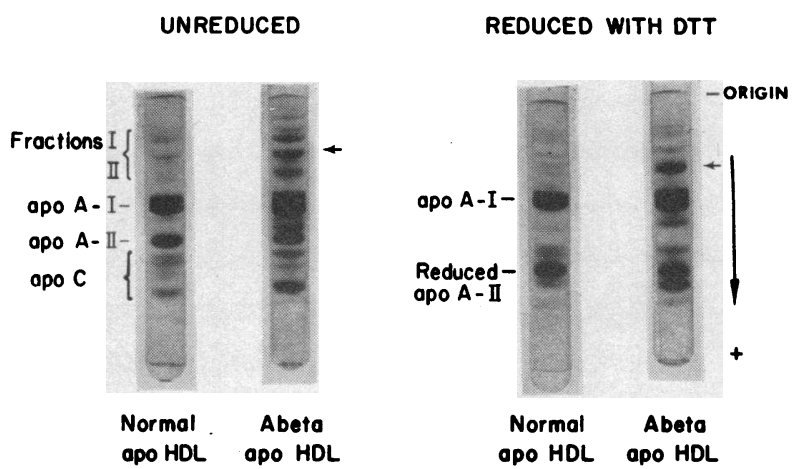

Figure 3 Polyacrylamide gel (10\% acrylamide) electrophoresis in $0.1 \%$ SDS of normal and ABL HDL before and after reduction with DTT. Amount of protein added to each gel : $120 \mu \mathrm{g}$. Fractions I and II are the high-molecular weight components that elute before apo A-I on Sephadex column chromatography (14). In this method no stacking gel is used.

and the intermediates. Thus, density gradient ultracentrifugation failed to separate distinct lipoprotein species.

$V H D L_{1}$. The concentration of this fraction was on the average $50 \%$ lower than in normals. By SDS-polyacrylamide gel electrophoresis it appeared to be contaminated by albumin, as indicated by molecular weight criteria and immunological studies. Its band pattern was otherwise similar to that of $\mathrm{ABL} \mathrm{HDL}_{2}$ or $\mathrm{HDL}_{3}$ except that in $\mathrm{ABL}$ the bands corresponding to apo $\mathrm{C}$ were only present in trace amounts.

Lipid studies. The protein: lipid ratios in "LDL", $\mathrm{HDL}_{2}$, and HDLs were within the ranges reported for the corresponding classes in normal human sera. The whole HDL exhibited a significant decrease in the content of cholesteryl esters (Table V) and changes in the

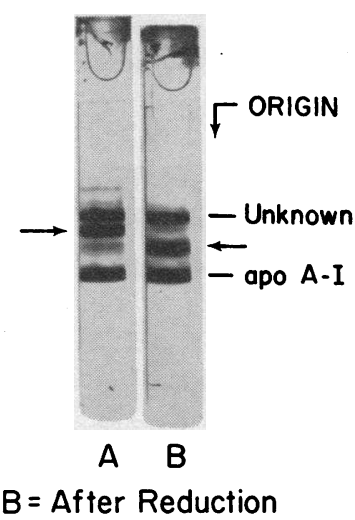

FIGURE 4 Polyacrylamide gel electrophoresis in SDS ( $0.1 \%$ SDS, $10 \%$ acrylamide) of Sephadex fraction II. Amount of protein applied to each gel: $120 \mu \mathrm{g}$. The arrows indicate the component whose mobility was influenced by DTT. No stacking gel is used in this method of electrophoresis. 
lecithin: sphingomyelin percent distribution (53:38\% in the five patients as compared with $82: 12$ in controls). Similar differences were also noted in $\mathrm{HDL}_{2}$ and $\mathrm{HDL}_{3}$ (Table V). Fatty acid analysis of HDL lipid classes showed a decrease in the percentage of the two essential fatty acids of $18: 2$ and $20: 4$. The change in linoleic acid was most evident in the cholesterol ester fraction, whereas the change in arachidonic acid was in the sphingomyelin fraction.

In the case of VHDL $\mathrm{V}_{1}$ there were no significant differences in the protein: lipid ratios between normal and $A B L$ patients, and the result were in general agreement with those reported by Alaupovic, Sanbar, Furman, Sullivan, and Wolraven (25).

Studies with $L C A T$. In ABL plasma from patients A.M.V. and M. S., the activity of LCAT was reduced to $2.1 \%$ and $0.96 \%$, respectively, compared to the normal range of $3-5 \%$ (Table $\mathrm{VI}$ ). A reduction in activity was also noted in patient G.F. Addition of heat-inactivated HDL from a normal subject to $A B L$ plasma resulted in the doubling of the amount of free cholesterol esterified. When HDL derived from a patient with LCAT deficiency was added to the incubation mixture, the stimulation of enzyme activity resulted in esterification of 16 and $7 \mu \mathrm{g}$ of free cholesterol, respectively (patients A. M. V. and M. S.). Further, the addition of whole plasma from LCAT-deficient patients to plasma

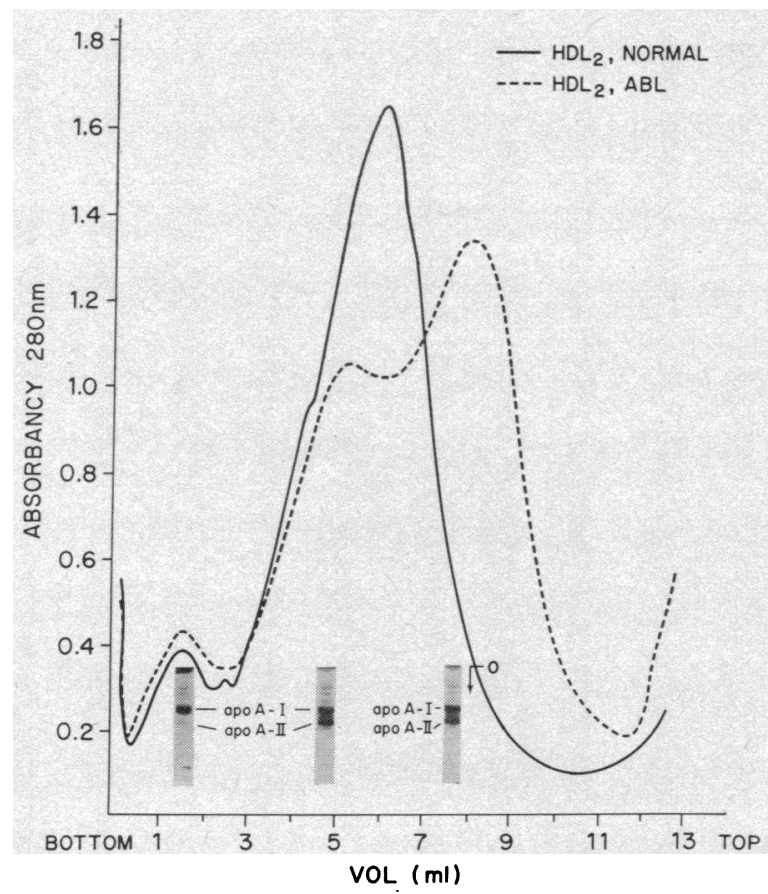

FIGURE 5 Density gradient profiles of $\mathrm{HDL}_{2}$ from normal and $A B L$ subjects (upper panel). The insets are $0.1 \%$ SDS, $10 \%$ polyacrylamide gel patterns of cuts from the ultracentrifugal bands of an $\mathrm{ABL}$ subject.
TABLE V

Lipids in $A B L$

\begin{tabular}{|c|c|}
\hline Patient & $\begin{array}{c}\text { Cholesterol } \\
\text { unesterified: esterified }\end{array}$ \\
\hline & ralio of percentage \\
\hline \multicolumn{2}{|r|}{ 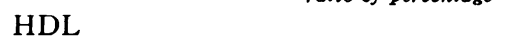 } \\
\hline A. M. V. & $38: 62$ \\
\hline D. P. & $41: 59$ \\
\hline M. S. & $42: 58$ \\
\hline R. I. & $45: 55$ \\
\hline G. F. & $40: 60$ \\
\hline Average & $41: 59$ \\
\hline Control & $20: 80$ \\
\hline \multicolumn{2}{|l|}{$\mathrm{HDL}_{2}$} \\
\hline A. M. V. & $39: 61$ \\
\hline M. S. & $40: 60$ \\
\hline G. F. & $41: 59$ \\
\hline Average & $40: 60$ \\
\hline Control & $17: 83$ \\
\hline \multicolumn{2}{|l|}{$\mathrm{HDL}_{3}$} \\
\hline A. M. V. & $27: 73$ \\
\hline M. S. & $27: 73$ \\
\hline G. F. & $20: 80$ \\
\hline Average & $25: 75$ \\
\hline Control & $18: 82$ \\
\hline \multicolumn{2}{|c|}{ Lecithin:sphingomyelin } \\
\hline \multicolumn{2}{|c|}{ HDL } \\
\hline A. M. V. & $53: 41$ \\
\hline D. P. & $42: 35$ \\
\hline M. S. & $58: 39$ \\
\hline R. I. & $58: 34$ \\
\hline G. F. & $55: 39$ \\
\hline Average & $53: 38$ \\
\hline Control & $82: 12$ \\
\hline
\end{tabular}

from three $\mathrm{ABL}$ patients resulted in esterification of $28.4,20.1$, and $17.4 \mu \mathrm{g}$ of cholesterol $/ \mathrm{mI}$ per $\mathrm{h}$, values that approached the range of LCAT activity in normal subjects $(25-40 \mu \mathrm{g} / \mathrm{ml}$ per $\mathrm{h})$.

\section{Studies on delipidated apoproteins}

$A p o-" L D L "$. By polyacrylamide gel electrophoresis in $8 \mathrm{M}$ urea, apo-"LDL" exhibited two major and three minor bands. This pattern resembled that of ABL apo HDL (described below) rather than of normal LDL. The presence of apo A-I, apo A-II, and apo $\mathrm{C}$ was also shown by SDS-polyacrylamide gel electrophoresis, and by the immunological results (Table VII).

Apo HDL, apo HDLs, and apo HDL. Studies by Ouchterlony double diffusion and immunoelectrophoresis showed that $\mathrm{ABL}$ apo $\mathrm{HDL}_{2}$, apo $\mathrm{HDL}_{3}$, and $\mathrm{HDL}$ reacted against anti-apo A-I, apo A-II, and apo $\mathrm{C}$ antisera from normal HDL and in each case formed lines of identity with norml apo HDL and its subfractions. 
TABLE VI

Cholesterol Esterification in ABL Plasma

\begin{tabular}{lllllll}
\hline \multicolumn{1}{c}{ Addition } & \multicolumn{2}{c}{ A. M. V. } & \multicolumn{2}{c}{ M. S. } & \multicolumn{2}{c}{ G. F. } \\
\hline & $\% / h$ & $\mu g^{*}$ & $\% / h$ & $\mu g$ & $\% / h$ & $\mu g$ \\
None & 2.1 & 2.7 & 0.96 & 1.5 & 1.37 & 1.2 \\
+ HDL & 1.6 & 5.9 & 0.70 & 3.0 & - & - \\
+ HDL $\$$ & 1.95 & 16.3 & 0.85 & 7.0 & - & - \\
+LDL $\|$ & 0.96 & 9.5 & 0.53 & 5.5 & - & - \\
+LCAT-deficient & & & & \\
$\quad$ plasma & 1.4 & 28.4 & 0.87 & 20.1 & 1.279 & 17.4 \\
Normal & $3-5$ & $25-40$ & & & & \\
\hline
\end{tabular}

Incubation contained $0.5 \mathrm{ml}$ of ABL plasma, $0.5 \mathrm{ml}$ of LCAT-deficient plasma, $0.25 \mathrm{ml}$ of $\mathrm{HDL}$ (corresponding to $\mathrm{HDL}$ from $1 \mathrm{ml}$ of normal plasma), and $0.25 \mathrm{ml}$ of $\mathrm{LDL}$ (corresponding to LDL from about $0.5 \mathrm{ml}$ of LCAT-deficient plasma). Equal volumes were obtained by addition of normal saline. All incubations contained $0.2 \mathrm{ml}$ of $5 \%$ BSA coated with radioactive cholesterol, and $0.25 \mathrm{ml}$ of $10 \mathrm{mM}$ Ellman reagent. The reaction was started after $4 \mathrm{~h}$ of preincubation with the addition of $0.05 \mathrm{ml}$ of $0.1 \mathrm{M}$ mercaptoethanol. The incubation time was $1 \mathrm{hr}$.

* Micrograms of free cholesterol esterified per hour by LCAT present in $1 \mathrm{ml}$ ABL plasma.

I HDL from a normal male, heat-inactivated $\left(1 \mathrm{~h}, 56^{\circ} \mathrm{C}\right)$.

$\$$ HDL from a patient with familial LCAT-deficiency.

|| LDL from a patient with familial LCAT-deficiency.

I The LCAT-deficient patient used for G. F. was not the same one used for A. M. V. and M. S.

No reaction of any of the $A B L$ fractions was noted against anti-LDL antisera.

The polyacrylamide gel electrophoretic patterns $(0.1 \%$ SDS and $10 \%$ acrylamide) of apo $\mathrm{HDL}_{2}$ and apo $\mathrm{HDL}_{3}$ were indistinguishable from those observed with the undelipidated $\mathrm{HDL}_{2}$ and $\mathrm{HDL}_{3}$, both in terms of identifiable and unknown bands (Fig. 3 ).

By $7.5 \%$ polyacrylamide gel electrophoresis in $8 \mathrm{M}$ urea, the additional difference between normal and $A B L$ apo HDL (Fig. 6) was the absence in the latter of one of the apo $\mathrm{C}$ bands, namely apo C-III-I.

Chemical studies. Two methods, Sephadex G-200 chromatography in $8 \mathrm{M}$ urea and DEAE ion-exchange chromatography in $6 \mathrm{M}$ urea, were used to fractionate apo HDL and apo HDL. By Sephadex G-200 chromatography, the elution profile of ABL-apo HDL differed from normal (Fig. 7) in having comparatively larger peaks I and II and by the presence of a shoulder in an

TABLE VII

Summary of Immunological Results of A polipoproteins in $A B L$

\begin{tabular}{lccccc}
\hline $\begin{array}{l}\text { Antibody } \\
\text { Antigen }\end{array}$ & $\begin{array}{c}\text { Anti- } \\
\text { LDL }\end{array}$ & $\begin{array}{c}\text { Anti } \\
\text { apo } \\
\text { HDL }\end{array}$ & $\begin{array}{c}\text { Anti } \\
\text { apo } \\
\text { A-I }\end{array}$ & $\begin{array}{c}\text { Anti } \\
\text { apo } \\
\text { A-II }\end{array}$ & $\begin{array}{c}\text { Anti } \\
\text { apo } \\
\text { C }\end{array}$ \\
\hline "VLDL-LDL" & - & + & + & + & + \\
HDL2 & - & + & + & + & + \\
HDLs & - & + & + & + & + \\
HDL & - & + & + & + & + \\
$\begin{array}{l}\text { Bottom } \\
\text { fraction }\end{array}$ & - & + & + & + & + \\
\hline
\end{tabular}

area between peaks III and IV. ${ }^{2}$ An analysis of this shoulder by SDS-polyacrylamide gel electrophoresis showed apo A-I, apo A-II, and two intermediate bands with molecular weight of about 22,000 and 20,000. One of the intermediate bands was seen with normal apo HDL but its relation to those in ABL was not established. Also, one of the intermediate bands (mol wt 20,000 ) was affected by reduction with DTT or $\beta$-mercaptoethanol. Fractionation of ABL-apo HDL by DEAE-ion exchange column chromatography (Fig. 8), was found to give a better separation of the intermediates. The intermediate sensitive to reduction was eluted in the area between apo A-I and apo A-II and was heavily contaminated by these two fractions. The other intermediate was eluted in the first DEAE peak. This peak, by SDS-polyacrylamide gel electrophoresis, comprised two major components with estimated molecular weights of about 22,000 and 10,000 (see Figs. 8 and $10)$. These two components were separated by Sephadex G-200 column chromatography (Fig. 9). Component $b$, on SDS polyacrylamide gel electrophoresis, showed a major band with a molecular weight of approximately 10,000 and a minor contaminant of molecular weight of 22,000 (Fig. 10). Further purification of component $b$ by Sephadex column chromatography $(1.6 \times 200-\mathrm{cm}$ column; equilibrating and elutive buffer, $0.1 \mathrm{M}$ Tris, $\mathrm{pH} 8.2,8 \mathrm{M}$ urea, flow rate, $7.5 \mathrm{ml} / \mathrm{h}, 5^{\circ} \mathrm{C}$ ) yielded a protein that exhibited a single band $(\mathrm{mol} \mathrm{wt} \simeq 12,000$ ) by SDS polyacrylamide gel electrophoresis and had the immunological and chemical properties of apo C-I. Component $a$, representing the intermediate, exhibited a single band by SDS polyacrylmide gel electrophoresis ( $\mathrm{mol} w \mathrm{t}=22,000)$ and an amino acid composition ( $\mathrm{Ta}-$ ble VIII) distinct from that of apo A-I and apo A-II or from any of the lipoprotein polypeptides described so far (4). This intermediate was not noted in the normal subjects studied. A thorough physicochemical characterization of this polypeptide is in progress. ABL apo A-I

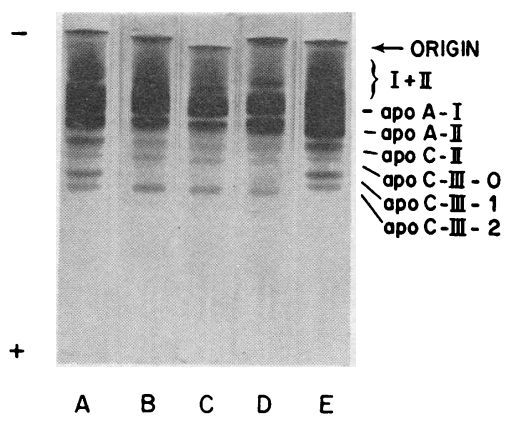

Figure 6 Polyacrylamide gel electrophoresis $7.5 \%$ in $8 \mathrm{M}$ urea of normal and ABL HDL. A and E, normal; B, C, and $\mathrm{D}$, three different $\mathrm{ABL}$ subjects. The arrow indicates the top of the gel; no stacking gel was used. Approximately $400 \mu \mathrm{g}$ of protein was applied to each gel. 


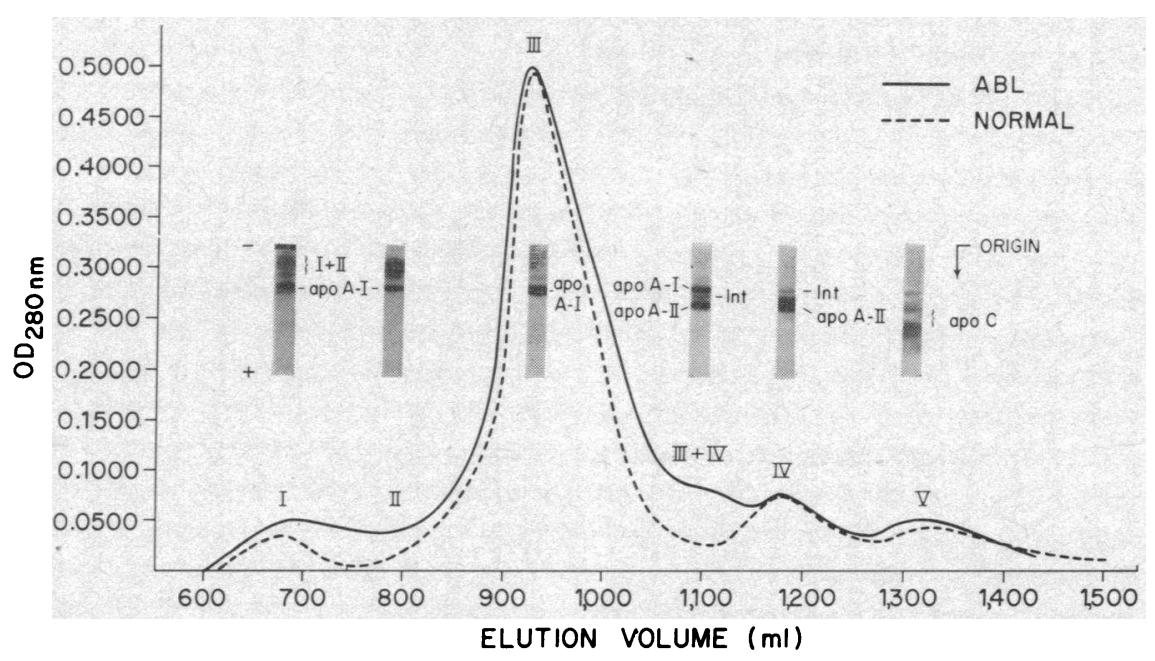

Figure 7 Sephadex G-200 chromatography, in $8 \mathrm{M}$ urea, of apo $\mathrm{HDL}_{2}$ from normal and ABL subjects. The insets represent SDS-polyacrylamide gel patterns of fractions at each of the points in the elution profile.

and apo A-II had the same amino acid composition as their normal counterparts (Table VIII).

To define the abnormality in the apo $C$ polypeptides observed by polyacrylamide-8 $\mathrm{M}$ urea gel electrophoresis of ABL-HDL (see Fig. 6) we subjected apo HDL from either normal or ABL patients to neuraminidase cleavage and then analyzed it by polyacrylamide gel electrophoresis in $8 \mathrm{M}$ urea. In both instances, the two fastest migrating bands disappeared; this is compatible with the conversion of apo C-III-I and apo C-III-2, containing 1 and 2 mol of sialic acid, respectively, into apo C-III-0, the peptide without sialic acid (26). Neuraminidase cleavage was also carried out on apo $C$ peptides. Neuraminidase treatment again affected the two fastest migrating bands, suggesting that desialylation was the cause of the phenomenon. Further validation of this conclusion was provided by fractionation of the apo $C$ peptides by ion-exchange chromatography according to the method developed in this laboratory, ${ }^{3}$ followed by chemical analysis of the individual fractions.

\section{DISCUSSION}

The present study has provided additional evidence that the metabolic defect in ABL is a complex one (27) and affects all classes of plasma lipoproteins, although to varying degrees. The genetic nature of the observed lipoprotein abnormalities appears to be supported by the fact that these abnormalities were expressed equally in all of the patients studied regardless of sex, age, ethnic group, nutritional or drug regime, or disease state. We have shown, in agreement with data in literature $(1,2)$, that a major defect in ABL is the absence of an im-

${ }^{3} \mathrm{~L}$ im, C. T., and A. M. Scanu. Manuscript in preparation. munologically detectable LDL protein in the circulation. This lack of immunological reactivity either indicates that the "native" LDL protein is absent in ABL plasma or that, if present, its structure is so altered that its antigenic properties are affected. The presence of an "abnormal" LDL polypeptide in ABL has been postulated by Lees (28), primarily on the basis of immunological studies. However, this concept is still in need of stringent experimental corroboration.

Another interesting abnormality, detected in the plasma of all of our patients, was the presence of lipoprotein particles occurring in minute amounts with flotational properties of LDL. These particles, referred to as "LDL", have previously been noted by Levy, Fredrickson, and Laster (4) and were considered to represent an unusually fat-rich HDL. On the other hand, our studies have shown that these particles, although possessing the major HDL apoproteins, have, overall properties of neither normal LDL nor HDL, and that their structure has not been observed with ultracentrifugally generated products in HDL (24). Their morphological appearance in the electron microscope was particularly intriguing. As previously noted by Forte and Nichols (6), the appearance of these particles was rather distinct from that of normal LDL or HDL, probably as a consequence of an unusual behavior under the conditions of microscopic examination. An abnormal lipoprotein morphology has also been reported for the lipoprotein of obstructive jaundice $(29,30)$ and in subjects with LCAT deficiency (31). A particular feature of these lipoproteins is a disk-shaped structure seen under electron microscopy; this has been related to their low content of cholesteryl esters, which, in turn, is 


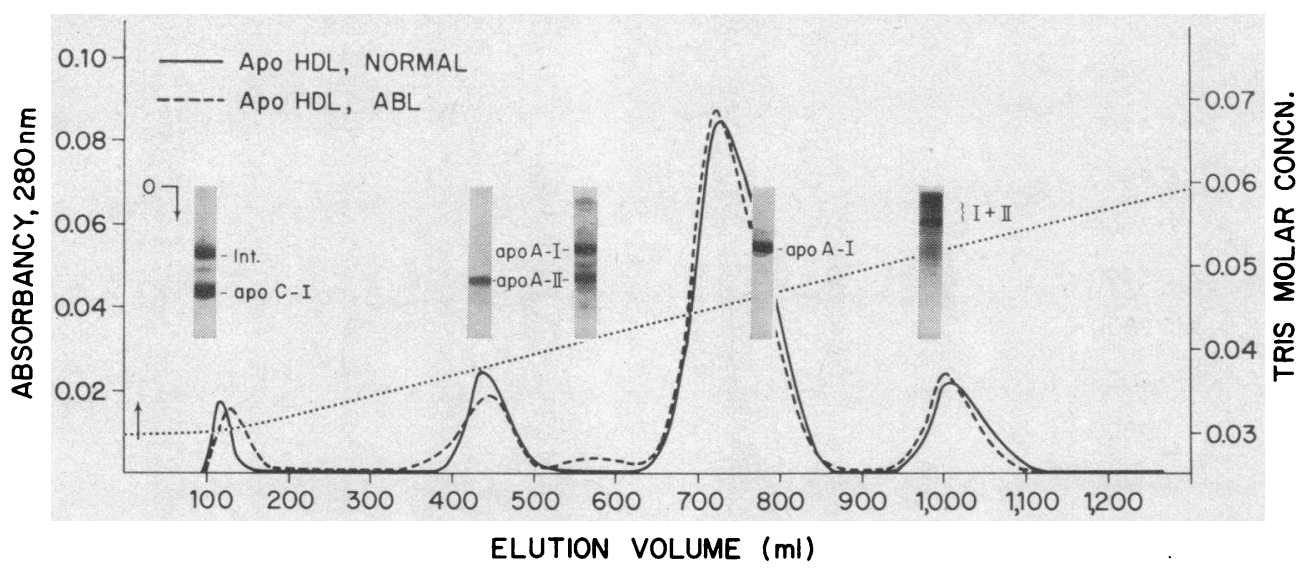

FIGURE 8 DEAE ion-exchange chromatography in $6 \mathrm{M}$ urea of apo $\mathrm{HDL}_{2}$ of normal and ABL subjects. The insets represent $0.1 \%$ SDS- $10 \%$ polyacrylamide gel patterns of ABL fractions at each of the points in the elution profile.

considered to be secondary to a deficiency of LCAT activity. Our ABL subjects showed a deficiency in LCAT activity together with a lower than normal cholesteryl ester content "LDL". This could have caused their unusual electron microscopic appearance, according to the concept that cholesteryl esters impart structural stability to serum lipoproteins (24). The nature of the decreased activity of the LCAT enzyme in ABL is not apparent. Cooper and Guldbrandsen (32) have reported that in $A B L$ there is a significant decrease in enzyme concentration, but their studies were limited to incubation of $A B L$ plasma by itself and $A B L$ plasma mixed with normal serum or with a synthetic phospholipid, dimyristoyl lecithin emulsified in saline. In our studies we selected more nearly physiological conditions and found indications that the activity of the LCAT in ABL plasma can approach the lower limits of the normal range provided appropriate components (substrate? activator?) are added. However, our work has failed thus far to establish whether the decrease in LCAT activity

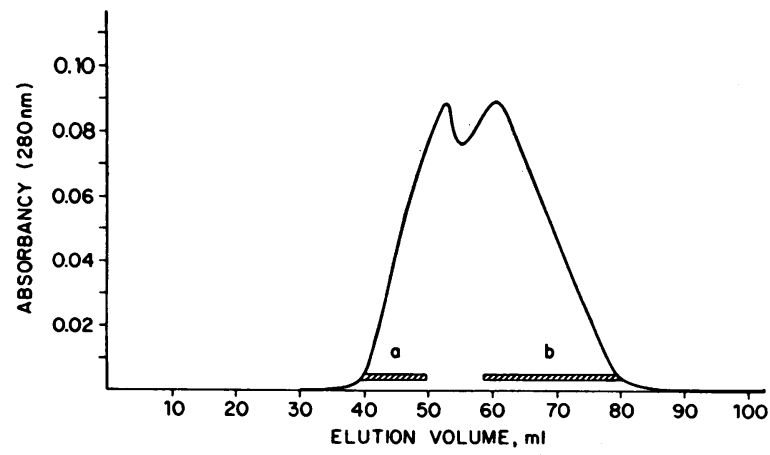

Figure 9 Sephadex G-200 (8 M urea) chromatography of ABL, DEAE, peak 1. For experimental conditions, see text. The fractions studied were those indicated by bars. was related to an actual enzyme defect or to a deficiency or abnormality of substrate or activators. This question remains open to further investigation.

In all of our five subjects significant anomalies were also noted in the HDL class. These anomalies were characterized by: ( $a$ ) marked reduction of the total plasma concentration of HDL, particularly affecting the $\mathrm{HDL}_{3}$ subclass, as has been noted previously by Jones and Ways (27); (b) a peculiar behavior of these particles when they were subjected to analytical ultracentrifugation or density gradient analysis in high salts; (c) unusual polypeptide distribution; (d) abnormality in sialylation of apo C-III and (e) abnormal lipid composition. The low plasma concentration of HDL in ABL remains unexplained but must be related to an imbalance of the mechanisms regulating their production, secretion, and degradation. It is important to stress that HDL were not only reduced in quantity, but were also qualitatively abnormal in their protein, lipid, and carbohydrate moieties. As for the protein moiety, a previous report by Gotto et al. (5) had indicated that the two major poly-

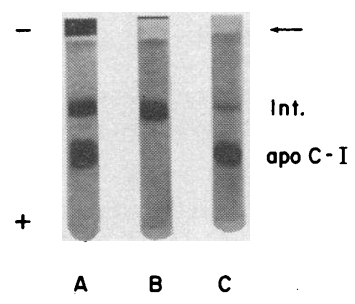

FIGURE 10 SDS-polyacrylamide gel electrophoresis of ABL, DEAE peak 1 and of the components obtained after separation of this peak by Sephadex G-200 chromatography. A, DEAE, peak $1 ; \mathrm{B}$, intermediate, mol wt $\simeq 22,000$ (Sephadex G-200 fraction $a$ ); C, apo C-I plus intermediate (Sephadex G-200 fraction $b$ ). 
TABLE VIII

Amino Acid Composition of apo A-I, apo A-II, and Intermediate in ABL

\begin{tabular}{|c|c|c|c|c|c|}
\hline \multirow[b]{2}{*}{ Amino acid } & \multicolumn{2}{|c|}{ Apo A-I $(\mathrm{mol} \mathrm{wt}=27,000)$} & \multicolumn{2}{|c|}{ Apo A-II $(\mathrm{mol} \mathrm{wt}=\mathbf{8 , 4 0 0})$} & \multirow{2}{*}{$\begin{array}{c}\text { Intermediate } \\
(\mathrm{mol} w \mathrm{t}=22,000) \S\end{array}$} \\
\hline & $\mathrm{ABL}$ & Control* & $\mathrm{ABL}$ & Controlt & \\
\hline & \multicolumn{5}{|c|}{ ( $\mathrm{mol} / \mathrm{mol}$ of prolein) } \\
\hline Aspartic & 18 & 18 & 3 & 3 & 16 \\
\hline Threonine & 10 & 10 & 6 & 6 & 8 \\
\hline Serine & 12 & 12 & 5 & 5 & 28 \\
\hline Proline & 10 & 10 & 4 & 4 & 8 \\
\hline Glutamic & 35 & 35 & 16 & 16 & 32 \\
\hline Glycine & 11 & 11 & 3 & 3 & 24 \\
\hline Alanine & 20 & 20 & 5 & 5 & 14 \\
\hline Valine & 12 & 12 & 6 & 6 & 8 \\
\hline$\frac{1}{2}$ Cystine $\|$ & 0 & 0 & 1 & 1 & $* *$ \\
\hline Methionine & 3 & 3 & 1 & 1 & 2 \\
\hline Isoleucine & 0 & 0 & 1 & 1 & 4 \\
\hline Leucine & 35 & 35 & 10 & 10 & 10 \\
\hline Tyrosine & 6 & 6 & 5 & 5 & 8 \\
\hline Phenylalanine & 6 & 6 & 5 & 5 & 6 \\
\hline Lysine & 20 & 20 & 10 & 10 & 10 \\
\hline Histidine & 6 & 6 & 0 & 0 & 8 \\
\hline Arginine & 17 & 17 & 0 & 0 & 6 \\
\hline Tryptophan $\mathbb{T}$ & 7 & 7 & 0 & 0 & 5 \\
\hline
\end{tabular}

The analyses represent the average of two determinations. The figures were adjusted to the nearest integer.

* Ref. 16.

$\ddagger$ Ref. 17.

$\S$ The analyses were carried out in triplicate in a Durrum Model D-500 amino acid analyzer (see Methods).

|| Determined as carboxymethylcystine.

I Determined spectrophotometrically (16).

** Present, but not quantified.

peptides of HDL, apo A-I and apo A-II are normally present in ABL. Our results confirm that finding, and also indicate that in both HDL and VHDL there are at least three protein bands that have not been described previously and that have molecular weights of about $59,000,22,000$, and 20,000 . The 22,000-dalton component, called "intermediate" because of its electrophoretic migration between apo A-I and apo A-II, was the only one isolated in pure form, and was found to have an amino acid composition distinct from all other apo HDL polypeptides described thus far. The structural and functional significance of these polypeptides is presently unknown; their thorough characterization is now in progress.

An additional abnormality in the HDL of ABL was related to the $C$ polypeptides. Gotto et al. (5) first reported by electrophoretic and chromatophographic criteria that apo C-III-I is not present in ABL. Our current studies have confirmed this observation and have provided additional proof by enzymatic criteria that in $A B L$ there is an oversialylation process favoring the formation of apo C-III-2, that is, the peptide containing $2 \mathrm{~mol}$ of sialic acid/mol of protein.
Besides exhibiting the above abnormalities, ABL HDL also differed from their normal counterparts in lipid composition. This difference was not only related to an abnormal distribution in free relative to ester cholesterol, as already discussed, but also included an abnormally high content of sphingomyelin and lecithin. These lipid abnormalities have been reported before (for review, see ref. 3), but have not yet been explained.

As we examine the overall experimental evidence gained thus far for $A B L$, it is apparent that there are numerous chemical anomalies in the circulating lipoproteins. Besides the well-recognized absence of normal LDL, these subjects have HDL that is both quantitatively and qualitatively abnormal, a peculiar "LDL", and a deficiency in the LCAT system. It is not clear at present whether all of the observed chemical abnormalities are related to each other and whether all have the same genetic basis. Obviously, there are many questions which can be answered only after further experimentation. For example, does the absence of circulating LDL affect the chemistry and metabolism of HDL? What regulates the mechanism of the conversion of $\mathrm{HDL}_{2}$ to 
$\mathrm{HDL}_{3}$ ? Why do HDL in ABL contain apo $\mathrm{C}$ peptides in spite of the absence of VLDL? What is the biochemical basis for the deficiency of LCAT activity? What is the significance of the additional polypeptides in apo HDL? There are other corollary problems associated with each of these questions, clear indications that the study of the metabolic basis of ABL is still incomplete. The conclusions to be reached from further studies will be relevant to an understanding not only of $\mathrm{ABL}$, but also of the mechanisms underlying fat transport and lipoprotein synthesis and metabolism under physiological conditions.

As a practical corollary to our findings, the term "abetalipoproteinemia" may no longer appropriately describe a disorder in which the abnormality within the circulating lipoproteins extends beyond the LDL class.

\section{ACKNOWLEDGMENTS}

The authors wish to acknowledge the valuable assistance and discussion by Dr. Lidia Vitello, Mrs. Celina Edelstein, Dr. Loring Bjornson, Miss Elizabeth Miller, Miss Michele Guerin, Mrs. Lynda Hatam, and Mr. Lance Lusk. The authors wish to express their thanks to Prof. Kaare Norum of the University of Oslo School of Medicine Institute for Nutrition Research, who carried out the determination on LCAT activity in the patients and collaborated in crossincubation studies with the plasma of patients with familial LCAT deficiency. They appreciate the cooperation of Professors Charles Back and Jean Rey of Paris, France, in providing plasma specimens from two of the ABL subjects studied.

This work was supported by Grants HL 08727 and HL 06481 from the United States Public Health Service, the Illinois and Chicago Heart Association (A72-6), and the Atomic Energy Commission.

The Franklin McLean Memorial Research Institute is operated by the University of Chicago for the United States Atomic Energy Commission. It was formerly the Argonne Cancer Research Hospital.

Nomenclature of apo HDL polypeptides: In apo HDL, apo A-I and apo A-II correspond to apo Gln-I and apo Gin-II or fractions III and IV. Fraction V corresponds to apo C. The "intermediate" refers to a polypeptide migrating by SDS-polyacrylamide gel electrophoresis between apo A-I and apo A-II. The major subfractions of apolipoprotein $\mathrm{C}$ are referred to as apo C-I, apo C-II, apo C-III-0, apo C-III-I, and apo C-III-2. According to another system, R-Ser $=$ apo C-I ; R-Glu = apo C-II, R = $\mathrm{Ala}_{0}=$ apo C-III-0, $\mathrm{R}=\mathrm{Ala}_{1}=$ apo $\mathrm{C}$-III-I, and R-Ala ${ }_{2}=$ apo CIII-2. For details on nomenclature, see review in reference 24.

\section{REFERENCES}

1. Kayden, H. J. 1972. Abetalipoproteinemia. Annu. Rev. Med. 23: 285 .

2. Fredrickson, D. S., A. M. Gotto, and R. I. Levy. 1972. Familial lipoprotein deficiency. In The Metabolic Basis of Inherited Disease. J. B. Stanbury, J. B. Wyngaarden, and D. S. Fredrickson, editors. McGraw-Hill Book Company, New York. Third edition. 493.
3. Skipski, P. V. 1972. Lipid composition of lipoproteins in normal and diseased states. In Blood Lipids and Lipoproteins: Quantitation, Composition and Metabolism. G. J. Nelson, editor. Wiley-Interscience, New York. 471.

4. Levy, R. I., D. J. Fredrickson, and L. Laster. 1966. The lipoproteins and lipid transport in abetalipoproteinemia. J. Clin. Invest. 45: 531.

5. Gotto, A. M., R. I. Levy, K. John, and D. S. Fredrickson. 1971. On the protein defect in abetalipoproteinemia. N. Engl. J. Med. 284: 813.

6. Forte, T., and A. V. Nichols. 1972. Application of electron microscopy to the study of plasma lipoprotein structure. Adv. Lipid Res. 10: 1.

7. Bach, C. H., J. Polonovski, C. Polonovski, R. Leluc, G. Jolly, and M. Moszer. 1967. L'Absence congenitale de B-lipoproteins. Arch. Fr. Pediatr. 24: 1093.

8. Farquhar, J. W., and P. Ways. 1966. Abetalipoproteinemia. In The Metabolic Basis of Inherited Disease. M. B. Stanbury, J. B. Wyngaarden, and D. S. Fredrickson, editors. McGraw-Hill Book Company, New York. Second edition. 509.

9. Ways, P., C. F. Reed, and P. J. Hanahan. 1963. Redcell and plasma lipids in an acanthocytosis. J. Clin. Invest. $42: 1248$.

10. Schwartz, J. F., L. P. Rowland, H. Eder, P. A. Markes, E. F. Osserman, E. Hirschberg, and H. Anderson. 1963. Bassen-Kornzweig syndrome: deficiency of serum B-lipoprotein. Arch. Neurol. 8: 438.

11. Lamy, M., J. Frezal, J. Polonovski, G. Druez, and J. Rey. 1963. Congenital absence of beta lipoproteins. Pediatrics. $31: 277$.

12. Scanu, A. M., and C. Edelstein. 1971. Solubility in aqueous ethanol of the small molecular weight polypeptides of very low- and high-density lipoproteins. Anal. Biochem. 44 : 576.

13. Pollard, H., A. M. Scanu, and E. W. Taylor. 1969. On the geometrical arrangement of the protein subunits of human serum low-density lipoproteins: evidence for a dodecahedrol arrangement. Proc. Natl. Acad.Sci.U.S. A. 64: 304.

14. Scanu, A. M., J. Toth, C. Edelstein, J. Koga, and E. Stiller. 1969. Fractionation of human serum high density lipoproteins in urea solutions. Evidence for polypeptide heterogeneity. Biochemistry. 8: 3309.

15. Fairbanks, G., T. L. Steck, and D. H. Wallach. 1971. Electrophoretic analysis of the major polypeptides of the human erythrocyte membrane. Biochemistry. 10: 2606.

16. Edelstein, C., C. T. Lim, and A. M. Scanu. 1972. On the subunit structure of the protein of human serum high density lipoproteins. I. A study of its major polypeptide component (Sephadex, Fraction III). J. Biol. Chem. $247: 5843$.

17. Scanu, A. M., C. T. Lim, and C. Edelstein. 1972. On the subunit structure of the protein of human serum high density lipoproteins. II. A study of the Sephadex fraction IV. J. Biol. Chem. 247: 5850.

18. Lowry, O. H., N. J. Rosebrough, A. L. Farr, and R. S. Randall. 1951. Protein measurement with the folin phenol reagent. J. Biol. Chem. 193: 265.

19. Franey, R. J., and E. Amador. 1968. Serum cholesterol measurement based on ethanol extraction of ferric chloride-sulfuric acid. Clin. Chim. Acta. 21: 255.

20. Chen, P. S., T. Y. Toribara, and H. Warner. 1956. 
Microdetermination of phosphorus. Anal. Chem. 28: 1756.

21. Van Handel, E., and D. G. Zilversmit. 1957. Micromethod for the direct determination of serum triglycerides. J. Lab. Clin. Med. 50: 152.

22. Karmen, A., M. Whyte, and D. Goodman. 1963. Fatty acid esterification and chylomicron formation during fat absorption. I. Triglycerides and cholesterol esters. J. Lipid Res. $4: 312$.

23. Stokke, K. T., and K. R. Norum. 1971. Determination of lecithin-cholesterol acyltransferase in human blood plasma. Scand. J. Clin. Lab. Invest. 27: 21.

24. Scanu, A. M. 1972. Structural studies on serum lipoproteins. Biochim. Biophys. Acta. 265: 471.

25. Alaupovic, P., S. S. Sanbar, R. H. Furman, M. L Sullivan, and S. L. Wolraven. 1966. Studies of the composition and structure of serum lipoproteins. Isolation and characterization of very high density lipoproteins of human serum. Biochemistry. 5: 4044.

26. Albers, J. J., and A. M. Scanu. 1971. Isoelectric fractionation and characterization of polypeptides from human serum very low density lipoproteins. Biochim. Biophys. Acta. 236: 29.

27. Jones, J. W., and P. Ways. 1967. Abnormalities of high density lipoproteins in abetalipoproteinemia. J. Clin. Invest. 46 : 1151 .

28. Lees, R. S. 1967. Immunological evidence for the presence of $B$ protein (apoprotein of $\beta$-lipoprotein) in normal and abetalipoproteinemic plasma. J. Lipid Res. 8: 396.

29. Seidel, D., B. Agostini, and P. Mullen. 1972. Structure of an abnormal plasma lipoprotein (LP-X) characterizing obstructive jaundice. Biochim. Biophys. Acta. 260: 146.

30. Hamilton, R. L., R. J. Havel, J. P. Kane, A. E. Blaurock, and T. Sata. 1971. Cholestasis: lamellar structure of the abnormal human serum lipoprotein. Science (Wash., D. C.). 172 : 475.

31. Forte, G. M., K. R. Norum, J. A. Glomset, and A. V. Nichols. 1971. Plasma lipoproteins in familial lecithincholesterol acyl transferase deficiency: structure of low- and high-density lipoproteins as recorded by electron microscopy. J. Clin. Invest. 50: 1141.

32. Cooper, R. A., and C. L. Guldbrandsen. 1971. The relationship between serum lipoproteins and red cell membranes in abetalipoproteinemia: deficiency of lecithincholesterol acyl transferase. J. Lab. Clin. Med. 78: 323. 